ROCZNIKI NAUK SPOŁECZNYCH

Tom 13(49), numer 3 - 2021

DOI: https://doi.org/10.18290/rns21493.9

\title{
DAVID REICHARDT
}

\section{AMERICAN COMMONALITIES AND ROOTS OF EUROPEAN INTEGRATION}

\section{INTRODUCTION}

European integration has been an ongoing, unique phenomenon. Robert Schuman, one of the key founders of the "European project" - the process of state integration which has become the European Union (EU) - famously described it as a "step by step" process. This signals that it involves both learning and attempting. If the attempts are well documented, from where did the learning arise? This article concentrates on one dominant source-the American-investigating the commonalties between the American and European integrative efforts and ultimately the American roots of European integration. The article first discusses integration in practice and thought, highlighting the divergent beginnings of the two integration efforts. It then turns to detail the uncanny subsequent parallels in American and European integration histories, including a discussion of the indirect and direct influences of the American federal model on the European project. It concludes with a review of the key assistance lent by the United States following the Second World War toward realization of a "United States of Europe."

\section{INTEGRATION IN PRACTICE AND THEORY}

When speaking of integration, the reference is to a specifically modern phenomenon. In other words, it is referring to the post-Westphalian world (1648-) of the modern state. It is a type of intensive cooperation among states, which

DAvid ReICHARDT, Ph.D. - Comenius University, Faculty of Social and Economic Sciences, Institute of European Studies and International Relations; address for correspondence: Mlynské luhy 4, 82105 Bratislava, Slovakia; e-mail: reichardtdavid@hotmail.com; ORCID: https://orcid.org/00000002-1579-1760. 
for various reasons agree to come together, voluntarily cede sovereignty to a central governing authority, and potentially head down a federal path. More formally, it is, as one scholar remarked:

the process whereby political actors in several distinct national settings are persuaded to shift their loyalties, expectations and political activities toward a new center, whose institutions possess or demand jurisdiction over preexisting national states (Haas, 1968, p. 16).

Once this is accomplished, one can refer to the new political entity as either an international governmental organization (IGO) with a central government possessing limited sovereign authority, or a super-state, in which sovereign authority is shared between the center and the member states - in other words, a "federal" arrangement.

Integration, therefore, is a process towards federalism, if not predetermined to end there. Although a subject of debate, many scholars recognize the first modern federal state as the United States of America (US), a country whose constitution divides authority between a central government and fully integrated states. In fact, some historians believe that the Americans literally "invented" federalism (Beer, 1978, p. 13), while history records no concrete examples of the voluntary integration of sovereign states prior to the founding of the United States of America. Thus, the American experience becomes the crucial starting point for any serious discussion of integration. It is also the reason why intellectuals and writers such as Victor Hugo spoke so adoringly of America and longed for a "United States of Europe." Later, statesmen such as Winston Churchill would adopt much the same language. There is little doubt that the founders of the European project looked to America as the premier example of what could be accomplished.

Yet, curiously, America and Europe began their integrative efforts quite differently. The United States started as a fully-fledged federal state, while the first European community merely flirted with federalism. One may see the differences more clearly in outline form of what was actually accomplished in the early years of each integration. The Americans, for their part, created a complété federal political union in 1789 with the following national governmental authorities:

- Internal improvements

- Subsidies (mainly to shipping)

- Taxation \& tariffs

- Disposal of public lands

— Immigration law 
— Foreign policy

- Copyrights

- Patents

- Currency (Lowi, 2006, p. 6).

By contrast, Europe began its integrative inception-The European Coal and Steel Community (ECSC) of 1952 - in a far more limited, circumscribed way, with six member states granting power to a High Authority along these lines:

— Free trade in coal and steel among member states

- Competition rules necessary for the functioning of the coal and steel market

- Common commercial trade policies in coal and steel (Eur-Lex, 2017, par. 1).

Why were the Americans able to speed ahead in integration as quickly as they did relative to the Europeans? Three considerations help to understand:

First is the issue of "trust." The American states had been united in a conflict against a common enemy for several years prior to integrating. Even after the American Revolution, they remained united in the Articles of Confederation government. Their chief concern was not whether there should or shouldn't be union, but about what type of "more perfect union" to craft. Using Karl Deutsch's terms, the Americans already had a "sense of community," which included mutual sympathy, loyalty, we-feeling, trust, mutual consideration, and perception of needs-prerequisites for integration (Deutsch, et al., 1957). The European states, by contrast, had recently been adversaries in the most destructive, horrific war known to modern man, so that an immediate leap into full political union among them was out of the question.

Second, socio-cultural and linguistic similarities greatly favored American integration over European. Not only did the Americans largely speak a common language, but the cultural bias across the states favored the Anglo-Saxon. Further, as the 13 states had been colonies of the British, their separate and extant governments all still reflected British political norms and customs. Although Europeans shared a culture of Christianity, their societies have simultaneously been multi-dimensional (Gizicki, 2009), reflecting a hodgepodge of ethno-national sub-cultures and disparate languages, further complicated by the devastation wrought by the Second World War, which initially resulted in an inward turn, rather than an outward search for cooperation.

Third, Americans had bona fide and renowned continental heroes lobbying for political union, such as Washington, Hamilton, and Franklin. By contrast there were few heroes that emerged from the Second World War. Robert Schuman and Jean Monnet, two of the key founders of the European communities, were 
hardly recognized names. In fact, one of the most recognized and respected personages, Winston Churchill, was not even in favor of a federated Europe, preferring loose confederal cooperation instead.

As a result of these differences, the United States could begin its integrated life holistically, "bursting through the front door," as it were, to propose an enhanced political union. By contrast, Europe's founding fathers-who certainly also had political union in mind-had to come "through the back door" of piecemeal economic integration to eventually achieve union. These considerations, however, only go so far in explaining why the early American and European integrations varied. To understand further, American and European intellectual thought is helpful. Unsurprisingly, early thinking on integration reflected both America's and Europe's unique social realities, so that on both sides of the Atlantic the focus was as much on propagation as on process. Normative and promotional motivations concerning integration were their driving force, highlighting the benefits of federation.

\section{AMERICAN INTEGRATIONIST THOUGHT: FEDERALIST}

American political thought relating to integration grew out of the idealism and liberalism of the late $18^{\text {th }}$ century. It was most famously represented in the writings of Alexander Hamilton, James Madison, and John Jay-which focused heavily on the new concept of federalism-simply because in the 1780 s, Americans were prepared for that debate. The authors were dealing with a situation in which an American union of sorts already existed, albeit a union-the Articles of Confederation - that was widely perceived to be flawed and far too weak to resolve the myriad of economic, political, and social problems present in post-revolutionary America. Thus, there is less emphasis on the "whys" of integration in their writings than arguments concerning the "type" of enhanced union and how it could work. In this way, the idea of a "more perfect union" was promulgated to highlight the need for a stronger bond among the states-a bond to which Madison himself would significantly contribute. For it was Madison who was arguably, more than any other American constitutional framer, the author of the American system of government.

Madison looked directly into the "political," arguing in favor of a single large republic, rather than a mélange of smaller republics (Madison, 1787a). In his Vices of the Political System of the United States, he detailed the weaknesses 
of the Articles of Confederation government, such as its inability to raise revenue through taxes, manage interstate commerce, and negotiate treaties with foreign countries (Madison, 1787b). Still, the question was how to integrate the separate states to strengthen the national government and resolve these problems. Madison extensively researched ancient and modern confederacies to improve upon their various designs. The result was a stroke of pure political genius - a federal system: a sharing of sovereignty between the states and national government, which became the "American political system" (Madison, 1788, in: Shafriz, Weinberg, 1994, p. 55). According to one historian:

The most creative contribution to the Democratic Experiment was the new Federal Republic of 1787. Modern federalism was born in 1787: the idea of a Union supreme in national matters, sharing certain powers with the component States of the Union, and denied powers in other spheres; the idea of a National Government, within its sphere able to act directly on the individuals who lived in the self-governing States of the Federal Union (Riemer, 1967, p. 213).

The US Constitution would be the contract, illuminating the dividing line between national and state authority, With the exception of new amendments, this is essentially the system still in place today.

\section{EUROPEAN INTEGRATIONIST THOUGHT: FUNCTIONALIST}

By contrast with Madison and the American founders-who assumed a certain degree of public acceptance of integration-early European integrationists could not take this for granted, as there was lack of precedent. Indeed, no purposeful European-wide union existed immediately prior to the creation of the European Coal and Steel Community. Thus, there was a greater need to explain "why" such a community should and could occur in the first place. "Peace" was the stated reason in the early writings of thinkers like David Mitrany, Altiero Spinelli, and Jean Monnet, and integration was the proposed solution, but that solution was going to be difficult to accept in a post-war environment of mutual mistrust. Countries that had recently been liberated from fascism were in little mood for high level partnership with their former oppressors.

Thought on European integration was, therefore, less assuming. Post-war European integrationists never took for granted the massive project they were 
undertaking. They clearly saw that Europeans must first be convinced that federal integration was a worthy goal in and of itself. As Jean Monnet implied in his memoirs, the obviousness that he saw in his wish for a federated integration, was not generally shared. As a result, Europe had to begin its integration piecemeal, beginning with the narrowly economic (coal and steel), and only later adding greater political integration after prolonged, sustained effort.

Those who favored this step-by-step approach, became known as "functionalists" because of the scholar who first advanced the term, David Mitrany. A highly original thinker, Mitrany was an idealist who sought an end to the problem of global war through a mechanism that would advance perpetual peace. He set out his "Functional approach" in a 1942 booklet, "A Working Peace System" - an idealistic view with a very practical component. With the Second World War raging, Mitrany was most concerned with the type of world to follow when the dust settled. His key concern was how to motivate cooperation among states in the new post-war world order so that war is a thing of the past. For Mitrany, the chief villain in disruptions to global peace was the nation-state inflamed with radical nationalism. Thus, any political system that can tamp down state nationalism is worth pursuing. Mitrany felt he found the answer in Functionalism (Mitrany, 1966). It begins with the recognition that all modern states, regardless of ideology, are essentially the same in their functions - the technical tasks for which they are responsible, such as energy, infrastructure, security, and trade. His great insight is that these very areas of functional commonality may be the basis of inter-state cooperation and subsequent integration if states could only see it in their interest to manage them collectively rather than apart. If so, it makes sense for states to create a central governing body to oversee their functional areas of concern-a body that has sovereign authority over the very states themselves in those functional areas. However, for Mitrany the idea went far beyond the transfer of technical functions to a central authority; over time there would be a transfer of the identity and loyalty of populations as well, lessening nationalism and the probability of future nationalistic conflicts.

Though it is not clear the degree to which Robert Schuman, Jean Monnet, Konrad Adenauer - the founders of the European Coal and teel Community-were familiar with Mitrany's writings, the ECSC represented a clear functional starting point, leading to "The Action Committee for the United States of Europe," which became the European Economic Community (EEC), the basis for the future European Union. 
In summation, where American integration could be boldly political from the outset, with calls for a US Constitution creating a fully formed, federal political system, European integration needed to proceed with measured caution along functional lines that would not overly excite or worry those not wholly convinced of the value of a federated Europe. Despite this, once begun, Europe's integration path proved remarkably similar to that of the American.

\subsection{AMERICA AND EUROPEAN INTEGRATION HISTORIES COMPARED}

To better see the parallels in the progression of American and European integration, it is useful to divide the pre-integration historical commonalities from those of the post-integration.

\subsubsection{Pre-integration Historical Commonalities}

\section{Backdrop of Conflict}

In both the American and European cases, a background of war was the main impetus for seeking greater cooperation among the states and, subsequently, integration. To be specific, both processes emerged from conflicts that were catastrophic "world wars." This is a point that is often overlooked, but the American Revolution was set in an era of world struggle involving-besides the American colonies and England-France, Spain, Holland, and those states allied or opposed to them (George, 2018). As for World War II, there is no debate as to its truly global character.

In fact, both wars were themselves products of earlier world conflicts that had left key issues unresolved. The American Revolution was a direct byproduct of the previous Seven Years War (1756-1763), while the Second World War is often seen as the result of unresolved issues from the First World War (1914-1918). In the case of the Seven Years War, the post-war desire by the British to extract tax revenue from the American colonies to pay for a long war that had literally "saved" them from the French, provoked Americans to rebellion. In the case of World War I, the Versailles process led to the carving up of Germany and war reparations imposed on the new Weimar government - issues that led to the rise of the Nazi party in the 1920s and its determination to oppose and eventually reverse these humiliating realities.

\section{New States}

Second, out of both the American and European war contexts, completely new states emerged. In North America, this took the form of 13 independent 
states, formed following the American Revolution. Likewise, in Europe, the post-World War I Versailles process led to the creation of Austria, Czechoslovakia, Hungary, Poland, and Yugoslavia, as well as newly reconstituted regimes following the Second World War in existing states. In many of them, territory was also redefined.

Also, in both the American and European cases, there was a common expectation that because of the tyranny that had so recently transpired, republican democracy must be the general political framework of the new states. In the case of the former British colonies this was the obvious aspiration of their leaders; in Europe after the Second World War, it was rather an expectation and imposition by the "western victors" in the conflict.

One key difference regarding the states, however, is that while the American states were all "winners" in their war, European states of the Second World War were a mix of "losers" (Austria, Germany), those that collaborated (Vichy France, Hungary, Slovakia), those that collaborated and switched sides toward the end (Bulgaria, Italy, Romania), and those that had been occupied and favored the Western Allies (Belgium, Luxembourg, the Netherlands, Denmark, Norway). This further highlights the point that a grand federation in post-war Europe, as had been accomplished in America, was simply outside the realm of possibility.

\section{Security Concerns}

A third commonality was the security concern. In the American case, there was real fear that the former colonies-now newly minted states-would not be able to survive alone. After all, it had been a mere six years since the Treaty of Paris (1783) ended the Revolutionary War, and despite that treaty, there was absolutely no guarantee that the British would not return at a later date to repeat their colonization project. As one noted historian observed, "danger is a strong cement" and there was plenty of danger in post-revolutionary America to encourage the states to work together (Bowen, 1986, p. 9). In fact, the British continued to have thousands of soldiers, ships and equipment stationed just to the north in British Canada, poised for action, which would eventually be realized in the War of 1812 .

Likewise, in the European case, one of the chief concerns was that Germany - though defeated-would rise again as it had following World War I. This was especially on the minds of the French, for whom integration was a solution for locking Germany down. With the beginning of the Cold War, the security concern was further compounded by the growing threat from the Soviet Union to the east. Thus, as in America, there was an urgency in Europe to interstate cooperation based in security fear. 


\section{Economic Concerns}

In both cases, security fears were intertwined with economic worries. That is, if economic stability were not quickly managed, political stability would soon be threatened, making the states even "easier prey" for aggressor states. In America, economic woes, symbolized by Shay's Rebellion in Massachusetts quickly followed the conclusion of revolutionary hostilities. In Europe, the situation was even more dire. Much of Europe had been so devastated by the war that several of the states literally could not cope alone. Although it is difficult to imagine today, Germany resembled a developing country in its first post-war years. Unable to feed its population, many thousands starved (Davidson, 1999, p. 85). France's economy was severely weakened, and Italy was in such disarray that numerous governments came and went. So, in both the American and European cases economic hardship was another common factor motivating cooperation and integration.

\section{Elite Leadership}

In both the American and European integrations, the respective founding fathers also shared personal commonalities. Here any number of framers could be mentioned, but arguably the three most instrumental in the formulation of the United States were Washington, Madison, and Hamilton, who can loosely be compared with European community founders Schuman, Monnet, and Adenauer. Politically, George Washington was necessary to get the American Constitutional Convention convened and running. Without Washington lending his name and prestige to the proceedings in Philadelphia, it is highly doubtful there would have been a convention at all. In the same vein, Robert Schumanthough clearly not the widely recognized hero that Washington was-had the political authority as former prime minister of France and current foreign minister to initiate the European Coal and Steel Community. Both men had admirable war records. While Washington had led the fight against the British, Schuman had been in active resistance to Nazi Germany. Also, both were recognized moral characters. Washington had the reputation for honesty and integrity, while Schuman held fundamental beliefs in the rights of man. Both were believed to be incorruptible. Indeed, because of his heroic virtues, Schuman has been declared "venerable" by the Catholic Church, a step on the path to canonization and sainthood (Vatican News, 2021, par. 1). Ultimately, both Washington and Schuman were able to leverage their positions and prestige to commence integration.

Then there are the personages of Madison and Monnet. One might characterize these two as the intellectual driving forces behind integration. As observed 
earlier, Madison almost single-handedly wrote the Virginia Plan, the plan which largely became the American Constitution. Monnet was the chief architect behind the Schuman Plan, which set out the first European community. Both were deep thinkers who clearly saw the dire need for an integrated effort in their respective spheres. Both were also ardent federalists. Madison saw federalism as a "middle ground" position that would "support the due supremacy of the national authority" while not excluding "the local authorities" (Carey, 1997, par. 16). Monnet believed that "only the establishment of a federation of the West" would enable Europe to solve its problems and "finally prevent war" (Monnet, 1978, p. 272).

Finally, there are Hamilton and Adenauer. Though there is great disparity in terms of their abilities - with Hamilton a recognized financial genius and Adenauer a talented politician, in another sense they were similar. Both represented states that were problematic yet critical for integration. Hamilton came to the Constitutional Convention representing New York, one of the most ardently "loyalist" states during the American Revolution-a state which had to overcome the perception of disloyalty to the revolutionary cause. It was also one of the wealthiest states, with a large commercial center in New York City - a wealth that would be needed in getting the young country started. Similarly, Adenauer was representing a country that was suspect-a country that a few years previously had initiated a world war. Yet like New York State in the American context, the Federal Republic of Germany was widely recognized to be the economic engine of any European post-war recovery. So, both men were important political actors, without which, no serious integration could take place.

Interestingly, the three men on each side were guided by high ideals, albeit stemming from vastly differing sources. Washington, Madison, and Hamilton were protestants, men of the Enlightenment period, while Schuman, Monnet and Adenauer were Roman Catholics, with Schuman, in particular, being motivated by Catholic principles of forgiveness, community and subsidiarity - all necessary building blocks of European integration. Yet, though all the men were motivated by high principles, they also had the unique ability to recognize practical considerations and urgent necessities, in particular the dire need for unity in the face of urgent challenges.

\subsubsection{Post-Integration Commonalities}

Following their first integrative efforts, both the United States and the European Community began their young lives relatively weakly, with member 
states of both projects clearly in control. In the United States, one could say that the states were even leading the union up and until the American Civil War. Historians sometimes refer to this as a period of "State-centered federalism," where the national government had yet to heavily involve itself domestically beyond land requisition and the creation of new territories and states. Emblematic of this period was a famous US Supreme Court case, Barron v. Baltimore (1833), which declared that claims for damages to property incurred by local government did not have to be resolved, because the US Constitution's liability provision only applied to the national government, not the states. Localities were under the authority of state constitutional law, not national. In fact, to emphasize the states in the federal relationship, prior to the American Civil War popular usage referred to the United States in the plural: the "United States are" rather than the "United States is" was the common formulation (Sbragia, 1992, p. 260).

European integration-which began even more narrowly with the Coal and Steel Community - was similarly "member-state led," with the six states of the Council of Ministers possessing final approval of all proposals of the High Authority in Brussels, and indeed only in the areas of coal and steel. The Treaty of Rome (1957), which created the European Economic Community, of course, greatly expanded the economic purview over which the high authority (titled the "Commission" for the EEC) exerted control-but the member states of the Council of Ministers still exercised their individual rights to veto Commission proposals.

However, throughout the state-centered period, the authority and power of the center was growing exponentially at the expense of the states. In the United States, this was largely accomplished through early strong Presidents, such as Monroe, Jackson, and Lincoln, and Supreme Court decisions such as McCulloch v. Maryland (1819), which established the national "Bank of the United States" and created the doctrine of "implied powers" - a principle first elucidated by Alexander Hamilton - through which the national government may exert authority not expressly mentioned in the US Constitution, if that authority may be logically linked to some authority that is so expressed.

Likewise, in Europe, despite the limited start, strong community presidents such as Walter Hallstein worked for new treaties in new areas of authority for the central government in Brussels. Most important among these early initiatives was a proposal by the Benelux countries ("Benelux Memorandum") which advanced the Treaty of Rome (1957), establishing the European Economic Community and calling for an "ever closer union among the peoples of Europe." 
Some European federalists expected this to inevitably lead to political federation, based on their understanding of the logical progression of the American experience (De La Serre, 1989).

\section{Early Difficulties}

Still, all was not immediately smooth with the beginnings of integration, as the young United States and the first European community experienced growing pains. The United States went through several economically motivated uprisings in its early years, which called into question the stability of the union. In one incident, the Whisky Rebellion, President Washington himself rode out to quell the rebellion.

In Europe, the first community of coal and steel was beset with problems, though not quite as dramatically as those of the American states. Chief among these was cheating by member states still aiming to protect their coal and steel markets. In a 1954 report, the High Authority of the community admitted that its price transparency efforts were failing because non-compliance with ECSC price policies was more the norm than the exception (Alter, Steinberg, 2007). This proved not to be a long-term problem, however, and the basic elements of the ECSC's institutional blueprint endured; it became the "boiler plate" in negotiations for the eventual common market (Alter, Steinberg, 2007).

The American Jacksonian Period and European Integration Compared

The Jacksonian period of American history, represented by the ascent of Andrew Jackson to the presidency of the United States (1829-1837), affords uncanny parallels with changes in the European Community in the 1970s and 80s. Three developments correspond for a rough fit. The Jacksonian period saw an expansion of land (new states), an extension of the voting franchise (new voters), and an extension of economic protection (new tariff policy). Likewise, the 1970s and 80s period in European integration saw the incorporation of 6 new member states - Denmark, Ireland, and the United Kingdom (UK) in 1973, Greece in 1981, and Spain and Portugal in 1986. In 1979, a legal change allowed citizens of European Community member states to vote for the first time for their representatives in the European Parliament. Finally, the Community's external tariff, which had been in place since 1968, was given a boost with the Single European Act (1987), resulting in a true "Common Market."

Despite these advances, all was not well. Various elites intervened to cause conflict. In the American case, it was President Jackson's political nemesis, the crafty South Carolina Senator, John C. Calhoun. Calhoun sparred over key issues, chief among them a US tariff proposal, which American southerners termed "The Tariff of Abominations." The tariff was proposed by northern 
interests and was intended to protect northern commerce at the expense of southern agriculture. If the European project had its "John C. Calhoun" one can say it has been Charles de Gaulle, for de Gaulle, more than other characters, made cooperation extremely difficult at times. He was always in favor of union, but in more of an intergovernmental or confederal union, dominated by France. The 1965 "Empty Chair Crisis," a boycott of Community institutions, was emblematic of the problems the European Economic Community had with de Gaulle. Later European candidates for the "Calhoun role" include Margaret Thatcher. As British prime minister, Mrs. Thatcher came along two decades after de Gaulle to challenge the European Community in terms of what the UK was paying into the budget, famously remarking in 1980, "I want my money back!" (BBC, 2013, par. 7).

\section{Backsliding: Secession in One Case, Separation in the Other}

Ultimate conflicts in federalism occur when one or more states decide to defect from the political arrangement. Both the United States and the European Union experienced this turmoil, albeit in varying ways. In the US, it was not entirely clear to many from the beginning the precise drawing line between the authority of the central government and that of the states. In fact, some of the states had threatened the union as early as the 1830s in the "Nullification Crisis" (South Carolina, 1832). In this ongoing period of state-centered federalism, it was widely believed that the states were advantaged in the delicate National-State sovereignty balance. This belief went hand in hand with the de facto situation in which the states did wield more day-to-day power and seeming authority than the national government, relatively distant in Washington D.C. Tensions percolated and finally exploded in the American Civil War (1861-1865). That violent and protracted conflict has often been attributed to the issue of "slavery," and indeed it was the proximate cause of the war. However, the overriding, sufficient cause was federalism. It was about which locus of government was going to lead these states of America-the center in Washington, or the states themselves? In other words, did the federal system give the states so much "reserved power" - as per the $10^{\text {th }}$ Amendment of the US Constitution - as to actually leave the union if they so chose? In the spring of 1861, seven southern states led by South Carolina believed so, and war ensued until union was restored in 1865.

Though far less dramatically, the European Union has also been no stranger to breakup, albeit through peaceful separation. The most noteworthy case, of course, involves the United Kingdom. After trying for years to enter the community, the UK finally succeeded in 1973, only to seemingly work for 
the next 30 years to diminish its participation and eventually withdraw from the European project in 2020 with "Brexit." The main issues involved sovereignty questions and what the British felt was political overreach by "Brussels." At the same time, there has been speculation that Greece, Portugal, and Spain might eventually defect over monetary issues, and Hungary and Poland over legal disagreements and rights concerns.

\section{Expansion}

In the parlance of integration, when one speaks of expansion, one is speaking of the twin phenomena of "wider and deeper." Wider implies a larger geographic union, incorporating new member states. "Deeper" means more integration-i.e., more federalism. In both the US and the EU cases, expansions of their respective unions have moved forward apace. In the United States, the country greatly widened following the Civil War to incorporate new states, Nevada, Nebraska, Colorado, North Dakota, South Dakota, Montana, Idaho, Wyoming, Utah, Oklahoma New Mexico, and Arizona. The war also settled the sovereignty question and ushered in the period of "Nation-centered federalism," represented by a new generation of political leaders eager to use the power of the national government to deepen domestic economic development (Martin et al., 1989), and-through the strong presidencies of William McKinley, Theodore Roosevelt, and Woodrow Wilson-craft for the first time a truly global US foreign policy. This deepening trend was further magnified during the presidency of Franklin D. Roosevelt, who advanced the power of the national government to create national economic development projects and employment and social welfare policies that went far beyond the stated authority given the national government in the US Constitution. Yet, he managed to get the US Supreme Court to uphold these policies, and that is all that mattered. Indeed, every subsequent US president has been held to a certain "Rooseveltian" standard of national activism (see Leuchtenburg, 2011).

In Europe, President Roosevelt might well be compared with the European Commission president of the 1980s and 90s, Jacques Delores. As a strong federalist, Delores was instrumental in the Single European Act (1987), the Treaty on European Union (1992), and monetary union-three major steps toward a more federal Europe. Like Roosevelt, he was lauded by those who supported his federal agenda but criticized by "Eurosceptics" who were opposed and insisted on an "opt-out" of the new EU policies. For his substantial integrative efforts, the European Council bestowed on Delores the title, "Honorary Citizen of Europe," in 2015. 


\section{THE AMERICAN ROOTS OF EUROPEAN INTEGRATION}

Yet, if the second theme of this article is that of the American roots of European integration, there must not only be clear commonalities between the two integrative histories, but actual evidence of influence. How did the American model of integration affect the formulation of the European Community, eventually leading to the European Union? The answer is both indirectly, through a transfer of ideas, and directly, through American motivation and post-war aid to Europe.

\subsection{THE TRANSFER OF IDEAS}

First, a number of the key founders of European integration were great admirers of the American system of government. Indeed, they spoke about it repeatedly and, as a result, post-war rhetoric on integration was replete with mentions of a "United States of Europe." In fact, the language and idea of a United States of Europe, as related to a United States of America, has a long history. Anecdotally, George Washington was said to be one of the first to utter the phrase, followed by Napoleon Bonaparte, while Polish writer Wojciech Jastrzębowski highlighted the phrase in his work, "About eternal peace between the nations" (Fulbright, 1948). The term was perhaps most famously employed by Victor Hugo, when he remarked,

A day will come when we shall see ... the United States of America and the United States of Europe face to face, reaching out for each other across the seas ... (International Peace Congress in Paris, 1849; Trove, 2021).

The United States of Europe concept was revived in the $20^{\text {th }}$ century by activist intellectuals such as Count Richard Coudenhove-Kalergi (Paneuropa movement, 1923), and politicians like French prime minister, Aristide Briand, who proposed concrete steps to realize it - steps interrupted by the great global economic depression and the Second World War. Due to the horrors of that conflict, the concept was revisited upon its conclusion. Winston Churchill picked up the mantle, remarking in a famous 1946 speech that: "We must build a kind of United States of Europe" (International Churchill Society, 2021). Certainly, one can say that by the late 1940s there was a desire on the part of European community founders to emulate something like a United States of America, in Europe. Indeed, evidence suggests they were keenly aware of the 
United States of America and its integration history. Jean Monnet lived and worked in the United States for extended periods of his life. He was an unabashed "Americanophile," greatly admiring what the Americans had accomplished through their integrative efforts. Indeed, Monnet held the American federal democratic system in highest esteem, specifically expressing his admiration for "Jay's, Madison's and Hamilton's Federalist Papers" (Monnet, 1978, p. 283). Monnet's writings make it crystal clear that he did not envision a European community of merely economic character, but one of political and federal as well. Yet, he also remarked that this will not be achieved in one broad stroke, as in the United States, but slowly and carefully:

... ought we to follow those who were urging an immediate move to the federal stage? I thought not .... Little by little the work of the Community will be felt, and the already distinguishable bonds of common interest will be strengthened. Then the everyday realities themselves will make it possible to form the political union, which is the goal of our Community, and to establish the United States of Europe (Monnet, 1978, p. 431).

Finally, Walter Hallstein, a founder of Europe who helped draw up the Schuman Plan and who was the first president of the Commission of the European Economic Community, was also deeply impressed and influenced by the United States. Hallstein developed a keen interest in American history between independence in 1776 and the ratification of the US Constitution in 1788, and he concluded that Europe should follow the American path towards a federal solution (Freiberger, 2010).

Overall, the evidence suggests that the positive example of the United States had a marked effect on those seeking to integrate Europe. Some theorists term such an effect, "social learning," or as the sociologist Richard Rose prefers "lesson drawing," in which programs and policies developed in one country inspire and are emulated by others and diffused throughout the world (Rose, 1991). Yet, whatever the process through which political ideas travel internationally, it is clear from the writings of Europe's founders that the American federal model and the idealism that inspired it were never far from their thinking. As Monnet wrote at the conclusion of his memoir:

We too are heading for our objective, the United States of Europe; and for us too, there is no going back (Monnet, 1978, p. 524). 


\subsection{DIRECT US ASSISTANCE AND MOTIVATION}

In addition to admiration for the American federal model and the desire to replicate it, Europe's founders had the added benefit of direct American assistance in the project. In the post-Second World War period, this assistance came in the form of motivation-a wellspring of American popular and professional opinion calling for a united Europe. According to one scholar, "a torrent of suggestions and proposals for a federated Europe poured in from every quarter of the United States," much of it through the popular media at the time, culminating in the US Congress successfully passing a resolution in March 1947 calling for a United States of Europe, which was subsequently featured in dozens of American newspapers and endorsed editorially (Rappaport, 1981, p. 123-124). While elite journalists such as Walter Lippman and Anne O'Hare McCormick advanced European integration in the press, key members of the US Congress worked the political side. US Senator William J. Fulbright became the leading senatorial proponent of European integration by

... heading citizens' committees, speaking on the Senate floor and throughout the country, writing articles, and corresponding on the subject with a wide variety of people. He always made the same plea-that the European nations draw up a constitution establishing a federation to provide for freedom of commerce, free movement of persons, a common currency, and efficient transportation. Such a federation, he believed, would result in a reduction of political rivalries and economic tensions and in a peaceful world (Rappaport, 1981, p. 123).

To that end, Fulbright created the American Committee for a Free and United Europe with the threefold objective: "to arouse public interest in a free and united Europe, assist the organization of a United States of Europe, and promote cordial relations between America and Europe." A nonprofit organization, its members included some of the most distinguished names in the political, business, and intellectual communities of the time (Rappaport, 1981, p. 127).

Meanwhile, other American elites worked assiduously to make European integration a reality. US Secretary of State George C. Marshall, for example, did not conceal his "deep sympathy" ... for a united Europe; in fact, the New York Times summed up a speech of his with the headline, "Marshall pleads for European unity" (Rappaport, 1981, pp. 124-125). His only concern was that the United States not impose upon Europe any particular form of political or economic association; it was Europe's decision (Rappaport, 1981, p. 124). 
The Marshall Plan of 1947/1948, which bears his name, was of crucial importance following the war in helping Europe rebuild and recover. It not only provided billions of US dollars for European recovery, but it also cleverly stipulated that those countries wishing to receive the funding must meet to cooperate and coordinate its usage. Indeed, one of the major objectives of the aid in the eyes of the US Congress - which approved the funding - was the creation of a European union, and that the United States should actively encourage its formation (Rappaport, 1981, p. 127). This led to the formation of the Organization for European Economic Cooperation (OEEC). Born in Paris, it was an outgrowth of the American recovery effort. The OEEC was one of the first major cooperative organizational initiatives in Europe following the war, and one wholly motivated by the Americans. Its 16 member states promised a "closer and everlasting cooperation." It certainly inspired Monnet, leading him to call for Europe, itself, to "take up the baton":

Everything I have seen and reflected on here leads me to a conclusion which is now my profound conviction: that to tackle the present situation, to face the dangers that threaten us, and to match the American effort, the counties of Western Europe must turn their national efforts into a truly European effort. This will be possible only through a federation of the West (Monnet, 1978, pp. 272-273).

Yet European federalists would never be alone in this project. United States support continued unabated, even covertly. A body known as the American Committee for a United Europe, or ACUE (not to be confused with Senator Fulbright's initiative) was created by former US Office of Strategic Services (OSS) alumni William Donovan and Allen Dulles and became the main conduit for funneling CIA funds in support of federalist projects in Europe, such as the Council of Europe and the Schuman Plan (Wilford, 2003). In fact, formerly classified American documents now reveal that the ACUE directly financed the European Movement, the most important federalist organization in the post-war years lobbying for a United States of Europe (Evans-Pritchard, 2000).

Finally, once the Schuman Plan was announced, it was still necessary for the Americans to "green light" the project, as the newly formed state of the Federal Republic of Germany (West Germany) was under American/Allied administrative control and needed the approval of the Allied High Commission for Germany, which had authority over Germany's energy policy. This they readily did. Regarding the approval, one scholar went so far as to assert, “... the Coal and Steel Community can be considered the product of a bargain struck between the Federal Republic and America, not France and West Germany" 
(Lovett, 1996, p. 425). Additionally, the Schuman Plan received the backing of the US Secretary of State, Dean Acheson, in alignment with President Truman. Acheson remarked: "we recognize with sympathy and approval the significant and far-reaching intent of the French initiative" (i.e., the Schuman Plan; Monnet, 1978, p. 306). So significant was American support for the European project that Harold Callender, the correspondent of the New York Times in Paris at the time, reportedly said, "Without American backing, the Schuman Plan would have stood very little chance of success" (Lovett, 1996, p. 452).

Thus, one may credibly assert that it was American initiative that got integration rolling in post-war Europe. Certainly, many scholars would agree that, minimally, without the Marshall Plan and the OEEC, there would have been a much-reduced probability of a Schuman proposal in 1950, and thus a serious European integration effort at that time.

\section{CONCLUSION}

The European integration project has evolved much since its relatively simple beginnings. It has progressed from a narrowly defined community of coal and steel to a major international organization with federal qualities. Moreover, it has provided the one thing that has eluded Europe for over a millennium-relative peace.

This article addressed the question, from where did the inspiration for the European project arise and the ability to realize it? To that end, the article first examined some of the critical points in the history of European integration, highlighting the divergent beginnings, but then the subsequent commonalities between the American and European integration experiences. Given the remarkable historical parallels between the two processes, the article put forward the idea of the American experience as a chief inspiration and root source of European integration. From the pre-integration conditions of post-war economic turmoil and security concerns to the post-integration steps of widening and deepening, both the American and European historical experiences have run very much in tandem. Moreover, scholarly sources suggest that Europe's founders were well aware of the American federal model and consciously sought to emulate, if not replicate it.

Further, the article suggested that without the historical example of the United States, as well as the massive American post-war assistance to Europe-enhanced by the dominating military and political role the United States 
played in Europe after World War II-it is highly doubtful that European integration would have commenced when and as it did.

This is not to imply that Europe's founders were relegated to a secondary role into the foray of state integration. On the contrary, Europe's early integrative efforts depended as much on the courage and foresight of men like Schuman and Monnet to take ideas from the American experience and make them a reality in Europe-no small task. For without their energy and vision, nothing of supranational significance would likely have been accomplished at the time.

Yet European federalists still needed a "model" on which to look back, and the United States provided precisely what was needed. Emerging from the Second World War, victorious and with unprecedented prestige, America-the land idealists associated with the illuminated "City on the Hill" of St. Matthew's Gospel-provided European federalists with both the model they sought and the support they needed towards their dream of a United States of Europe.

\section{BIBLIOGRAPHY}

Alter K., Steinberg D. (2007), The Theory and Reality of the European Coal and Steel Community, [in:] S. Meunier, K. McNamara (Eds.), Making History: European Integration and Institutional Change at Fifty, Oxford: Oxford University Press, pp. 89-104.

BBC (2013), Thatcher and Her Tussles with Europe, 8 April 2013, https://www.bbc.com/news/ uk-politics-11598879 [Accessed: 30.06.2021].

Beer S. H. (1978), Federalism, Nationalism, and Democracy in America, American Political Science Review, 72 (1), pp. 9-21.

Bowen K. D. (1986), Miracle at Philadelphia, New York: Bay Back Books/Little, Brown \& Company.

Carey G. W. (1997), In Defense of the Constitution, Carmel: Liberty Fund.

Davidson E. (1999), The Death and Life of Germany, Columbia: University of Missouri Press.

De La Serre E. B. (1989), Foreign Policy of the European Community, [in:] R. Macridis (Ed.), Foreign Policy in World Politics, States and Regions, Englewood Cliffs: Prentice Hall, pp. 345-373.

Deutsch K., et al. (1957), Political Community and the North Atlantic Area: International Organization in Light of Historical Experience, Princeton: Princeton University Press.

Eur-Lex (2017), Treaty Establishing the European Coal and Steel Community, ECSC Treaty, https://eur-lex.europa.eu/legal-content/EN/TXT/?uri=LEGISSUM\%3Axy0022 [Accessed 30.06.2021].

Evans-Pritchard A. (2000), Euro-Federalists Financed by US Spy Chiefs, The Telegraph, 19.09.2020, https://www.telegraph.co.uk/news/worldnews/europe/1356047/Euro-federalistsfinanced-by-US-spy-chiefs.html [Accessed: 30.06.2021].

Freiberger T. (2010), Der friedliche Revolutionär: Walter Hallsteins Epochenbewusstsein, [in:] V. Depkat, P. Graglia (Eds.), Entscheidung fuer Europa - Decidere l'Europa: Erfahrung, Zeitgeist und politische Herausforderungen am Beginn der europäischen Integration, Berlin, New York: De Gruyter, pp. 205-242. 
Fulbright W. J. (1948), A United States of Europe?, The Annals of the American Academy of Political and Social Science, 257(1), pp. 151-156, https://doi.org/10.1177/000271624825700116 [Accessed: 30.06.2021].

George A. (2018), The American Revolution was Just One Battlefront in a Huge World War, Smithsonian Magazine, https://www.smithsonianmag.com/smithsonian-institution/americanrevolution-was-just-one-battlefront-huge-world-war-180969444/ [Accessed: 30.06.2021].

Gizicki W. (2009), Development Issues of the European Union, [in:] W. Gizicki (Ed.), European Union Present and Future, Lublin: Catholic University of Lublin, pp. 197-194.

Haas E. (1968), The Uniting of Europe, Stanford: Stanford University Press.

Hugo V. (1849), Speech to the Peace Conference at Paris, https://trove.nla.gov.au/newspaper /article/12914658 [Accessed: 30.06.2021].

International Churchill Society (2021), United States of Europe Speech, 19 September, 1946, University of Zurich, https://winstonchurchill.org/resources/speeches/1946-1963-elder-statesman/ united-states-of-europe/ [Accessed: 30.06.2021].

Leuchtenburg W. (2011), In the Shadow of FDR: From Harry Truman to Barack Obama, Ithaca: Cornell University Press.

Lovett A. W. (1996), The United States and the Schuman Plan. A Study in French Diplomacy 1950-1952, The Historical Journal, 39 (2), pp. 425-455.

Lowi T. J. (2006), The End of the Republican Era, Norman: University of Oklahoma Press.

Madison J. (1787a), The Federalist 10, [in:] J. M. Shafriz, L. S. Weinberg (Eds.) (1994), Classics in American Government, Belmont: Wadsworth Publishing, pp. 210-215.

Madison J. (1787b), Vices of the Political System of the United States, National Archives, https://founders. archives.gov/documents/Madison/01-09-02-0187 [Accessed: 30.06.2021].

Madison J. (1788), The Federalist 39, [in:] J. M. Shafriz, L. S. Weinberg (Eds.) (1994), Classics in American Government, Belmont: Wadsworth Publishing, pp. 52-55.

Martin J. K., et al. (1989), America and its People, Volume One, to 1877, Glenview: Scott, Foresman \& Company.

Mitrany D. (1966), A Working Peace System, [in:] B. F. Nelsen, A. Stubb (Eds.), The European Union: Readings on the Theory and Practice of European Integration, Boulder: Lynne Rienner Publishers, pp. 93-113.

Monnet J. (1978), Memoirs, Garden City: Doubleday \& Company.

Nelsen B. F., Stubb A. (2003), The European Union: Readings on the Theory and Practice of European Integration, Boulder: Lynne Rienner Publishers.

Rappaport A. (1981), The United States and European Integration: The First Phase, Diplomatic History, 5(2), pp. 121-149.

Riemer N. (1967), The Democratic Experiment: American Political Theory-Volume I, Princeton: Van Nostrand Company.

Rose R. (1991), What is Lesson-Drawing, Journal of Public Policy, 11(1), pp. 3-30.

Sbragia A. M. (1992), Thinking About the European Future: The Uses of Comparison, [in:] A. M. Sbragia (Ed.), Euro-Politics, Washington D.C.: The Brookings Institution, pp. 257-291.

Shafriz J. M., Weinberg L. S. (Eds.) (1994), Classics in American Government, Belmont: Wadsworth Publishing. 
Vatican News (2021), Robert Schuman, Father of European Unity, on Path to Sainthood, 19 June 2021, https://www.vaticannews.va/en/pope/news/2021-06/robert-schuman-father-of-european-unityon-path-to-sainthood.html [Accessed: 30.06.2021].

Wilford H. (2003), Calling the Tune? The CIA, the British Left, and the Cold War, 1945-1960, Intelligence and National Security, 18(2), pp. 41-50.

\section{AMERICAN COMMONALITIES AND ROOTS OF EUROPEAN INTEGRATION}

Summary

This article looks deeply into the historical parallels between the American and European experiences of state integration, which have resulted in the United States of America and the European Union, respectively. It first defines the key international relations concept of state integration and compares American and European thought on the idea. It then turns to examine some of the highpoints in the history of integration in the American and European cases. Given the remarkable historical commonalties between the two processes, the article puts forward the idea of the American experience as a chief inspiration and source for European integration. It concludes by suggesting that without the historical example of the United States, as well as massive American post-war assistance to Europe, it is highly doubtful that European integration would have commenced when and as it did.

Keywords: integration; United States of America; European Union.

\section{GENEZA INTEGRACJI EUROPEJSKIEJ \\ W PERSPEKTYWIE AMERYKAŃSKICH DOŚWIADCZEŃ}

\section{Streszczenie}

Artykuł prezentuje zagadnienia dotyczące historycznych podobieństw w procesie integracji państwa w ramach doświadczeń amerykańskich i europejskich. Ich konsekwencją jest powstanie Stanów Zjednoczonych Ameryki i Unii Europejskiej. W pierwszej kolejności zdefiniowano kluczowe pojęcia z zakresu stosunków międzynarodowych i integracji państw. Następnie dokonano porównania myśli amerykańskiej i europejskiej w tym obszarze oraz wskazano na najważniejsze momenty integracyjne obu podmiotów. W artykule założono, że istnieją znaczne podobieństwa historyczne w przedmiotowych procesach. Dlatego też przedstawiono ideę doświadczenia amerykańskiego jako jednej z głównych inspiracji i źródła integracji europejskiej. Wniosek końcowy jest oparty na tezie, że bez historycznego przykładu, a także znacznej powojennej pomocy Stanów Zjednoczonych dla Europy wysoce wątpliwy jest początek i sposób realizacji idei integracyjnych w Europie.

Słowa kluczowe: integracja; Stany Zjednoczone Ameryki; Unia Europejska. 